\title{
RISK OF EXTINCTION AND PATTERNS OF DIVERSITY LOSS IN MEXICAN ORCHIDS
}

\author{
Miguel A. Soto Arenas ${ }^{1,3}$, Rodolfo Solano Gómez ${ }^{2}$ \& Eric Hágsater ${ }^{1}$ \\ Herbario AMO, Apdo. Postal 53-123, 11320 México D.F. MEXICO \\ ${ }^{2}$ Centro Interdisciplinario de Investigación para el Desarrollo Integral Regional, Unidad Oaxaca, Instituto \\ Politécnico Nacional. Hornos 1003, Santa Cruz Xoxocotlán, 71230, Oaxaca, Mexico. \\ ${ }^{3}$ Author for correspondence: msotoarenas@prodigy.net.mx
}

\begin{abstract}
RESUMEN. La norma oficial mexicana (NOM-059-ECOL-2001) lista cerca de 200 especies de orquídeas en alguna categoría de riesgo (Extintas, En Peligro de Extinción, Amenazadas y Sujetas a Protección Especial). Construimos una base de datos que incluye la información más relevante para planear las estrategias de conservación de estos taxa (nomenclatura, descripciones e ilustraciones para identificación, datos geográficos de todas las poblaciones conocidas, clima, hábitat, refugios, historia natural y ecología, características poblacionales, factores de riesgo, etc.). La información estará disponible través de la Comisión Nacional para el Conocimiento y Uso de la Biodiversidad, México (CONABIO). Con esta base de datos y usando sistemas de información geográfica se detectaron las áreas de concentración de orquídeas en riesgo y como éstas se relacionan con las Áreas Naturales Protegidas y las Áreas Terrestres Prioritarias para la conservación. Se discuten distintos patrones de riesgo, de amenazas y de pérdida de diversidad. Es evidente que los efectos del cambio climático, combinados con el mal manejo de los sistemas en hábitats únicos, constituyen las mayores amenazas. La erradicación de poblaciones de orquídeas en amplias zonas densamente pobladas y afectadas, especialmente en Veracruz y Puebla, pueden representar una pérdida importante de la diversidad genética total de las especies. Se hizo un esfuerzo especial por determinar las tasas de extinción de orquídeas en México. Finalmente, y de manera conjunta con otros biólogos de la conservación se desarrolló un método para evaluar el riesgo de extinción en plantas que está siendo adoptado por las autoridades del país y su uso pretende ser obligatorio en el futuro para la inclusión en las distintas categorías de riesgo.
\end{abstract}

KEY WorDs: Mexico, extinction rates, species at risk, threats, in situ conservation, natural protected areas

The orchid family comprises in Mexico some 1254 species and 21 subspecific taxa (Soto Arenas et al. 2007). Notable facts of the Mexican orchid flora are the very uneven distribution of the species in the territory, since about a half of the country is too dry to permit the existence of a single orchid species, and nearly $60 \%$ of the species are found in the cloud forests which occupy only about $1-2 \%$ of the area of the country (Soto Arenas 1996). A summary of the conservation actions in Mexico can be found in Hágsater and Soto Arenas (1998).

Like in other parts of the world, in Mexico the orchid diversity is being lost. Orchids have intrinsic biological traits that make them vulnerable and the human impact on their populations and habitats is a very important threat that is causing extinctions and significant losses of the species' genetic variation.

The Mexican Official Standard NOM-059-ECOL-
2001 lists 183 orchid species in a risk category (none extinct, 16 endangered, 61 threatened, and 106 under special protection). The official list is based on information gathered during the decade of 1980-1990 (Soto Arenas and Hágsater 1990; Soto Arenas 1994), nowadays the conservation status of some taxa has changed, even some taxa have become extinct. Based on the official list, and considering 15 additional taxa that have been reported as extinct or severely in risk in the last years, we constructed a data base that includes the most relevant information in order to plan the conservation strategies of the taxa at risk. The information will be soon available in BIOTICA, the data base of CONABIO, Mexico.

In this work we discuss three different aspects of the information derived from the orchids at risk data base: 1) Evaluation of the importance of current and proposed areas for conservation; 2) determination of 
the main risk factors, and 3) estimation of the extinction rates of a rich orchid flora that it is rather wellknown compared with many other tropical countries. This will permit us to suggest guidelines and conservation strategies with sound bases.

\section{Materials and methods}

DATA BASE. We obtained updated information for the nearly 200 Mexican orchids at risk, including nomenclature, distribution, climate, habitat, natural history, uses, ecology, risk factors, refuges, and possible conservation strategies (e.g. opportunities for in situ conservation, presence/absence in natural protected or prioritary regions, the maintenance feasibility outside of the habitat, etc.). This includes a review of literature, herbarium collections, field work, and experience cultivating and propagating the species. The information was captured in a data base using the Biotica 4.0 Information System (CONABIO). For each taxon a bibliographic revision and a list of every known locality, georeferenced, was recorded. This information will be available to the public from CONABIO, except for the precise location of sought-after taxa, subject to intense selective collection. Botanical illustrations, distribution maps, and photos were also included.

Populations AT RISK AND NATURAL PROTECTED AREAS. The whole of georeferenced populations of all the species at risk was superposed with a digital map of Mexico with its political division in states and showing the official Natural Protected Areas (CONANP, 2006) and the Priority Terrestrial Regions of Mexico (Arriaga et al. 2000). This was done using the program ArcView GIS 3.2.

RISK FACTORS. The two most important risk factors for every species of the 200 analyzed were assigned to one of the following categories: habitat conversion/destruction by agriculture, livestock grazing, due to effects of unpredictable climatic events (hurricanes, forest fires, unusual frosts), mining, urbanization, touristic developments, forestry, and charcoal production; habitat degradation by acidic rain, urban warming, by changes in the local hydrology; intrinsic biological factors, selective extraction for the local market, gathering for the international (often past) trade.
A method (MER, SEMARNAT 2002) to determine the risk status was applied to each taxon, since it is now mandatory by the Mexican regulation in order to have an objective assigment of the taxa in the different risk categories. We detected several problems of the method that systematically overestimated the extinction risk. Therefore, with the empirical information in the data base, and together with other conservation biologists, we designed and tested a more objective method to determine more precisely the risk categories. This new method considers a rarity index based in the criteria of Rawinowitz et al. (distributional traits, habitat characteristics, intrinsic biological vulnerability; 1986) and an anthropogenic impact index. The method will be available soon from the Mexican Ministry of Environment and Natural Resources (SEMARNAT) and will be mandatory to include any plant species in the Mexican official regulation.

EXTINCTION. It is very difficult to determine if a taxon is really extinct into an area or not. We critically examined every case of Mexican orchid that qualifies as extinct. Two different estimations were done. The first was done visiting all the known previous and verified stations, with searching specifically directed at the particular taxon, and corroborating its later extirpation; this approach gives us a high confidence in saying that a species is extinct. The second approach is less exhaustive, since verifying the extirpation of every known population was impossible to do, but there is circumstantial evidence that a particular taxon has disappeared, for example, very little suitable habitat remains, the habitat has been visited and surveyed by our team or other botanists with unsuccessful results, and/or there is an old date of last observation; this approach gives us an indication that the taxon is probably extinct. For example, Plectrophora alata (Rolfe) Garay was collected in Finca Hamburgo, near Huixtla, Chiapas, in 1935 and it has never been located again in the country. Documented populations exist in similar habitats in Suchitepéquez and Sacatepéquez, Guatemala, some $120 \mathrm{~km}$ eastward. Finca Hamburgo has been visited and little suitable habitat remains and $P$. alata has not been located by us or any other botanists that have visited the region. Since the region of the Soconusco, where the plantation is located has suffered extensive clearings and most land has been 


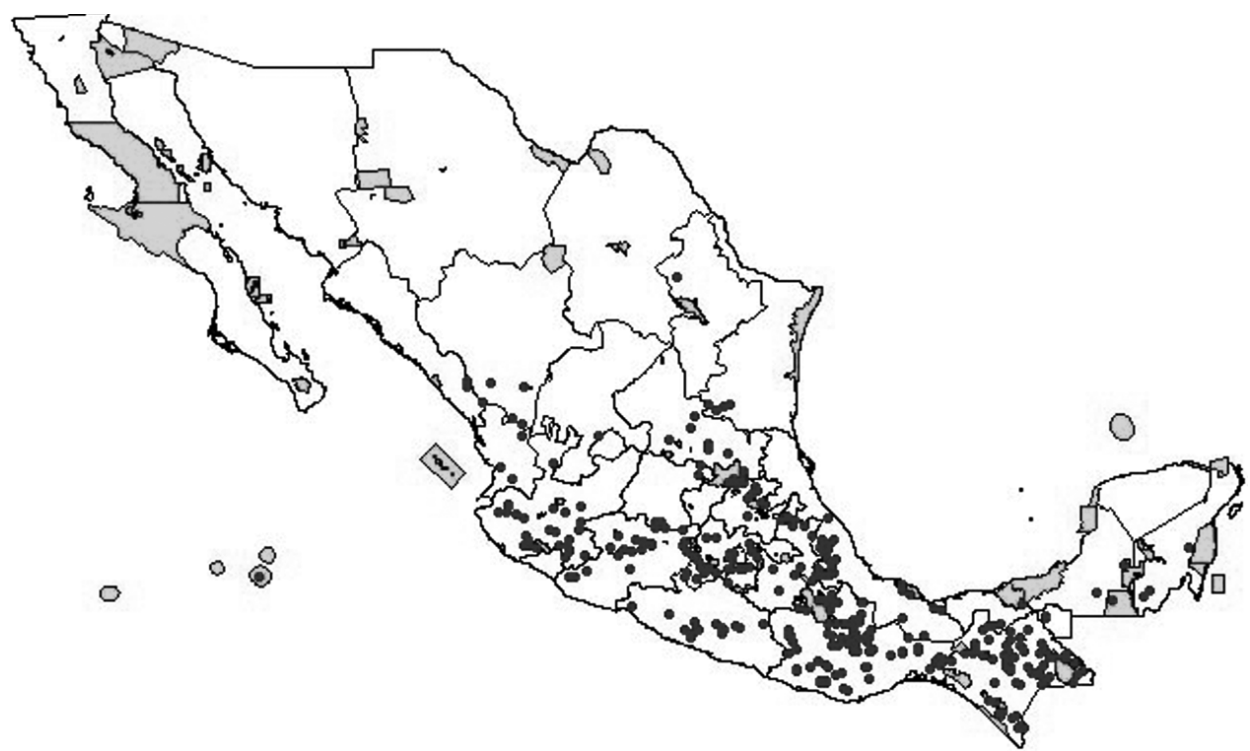

FIGURE 1. Localities of the Mexican orchids at risk (dots) and natural protected areas (in gray). There are 151 areas protected by the Mexican government (CONANP, 2006), but only 43 of them comprise orchid species at risk (15 biosphere reserves, 19 national parks, four natural monuments, and five areas of protection of flora and fauna). Only 120 orchid species at risk (from the 183 included in the NOM-059-ECOL-2001) have populations (at least one) in one of the protected areas. It is evident in the figure that most populations of orchids at risk are found outside of the protected areas, and that regions with a large number of populations of species at risk, as Veracruz, Guerrero, Oaxaca, and Chiapas, are almost devoid of protected areas.

converted into coffee plantations it is highly probable that $P$. alata is extinct in Mexico, as suggested by its last record 72 years ago.

We did not consider extinct those species that are very rare, little known, and in which no field work specifically directed to evaluate its populations and habitat has been conducted. For example, Malaxis lyonnetii Salazar is known only from one collection near Cuernavaca (Salazar 1997) and another from the nearby locality in Ocuilan (the type of M. andersoniana R.González, González Tamayo 2002). It is evidently very scarce, since this area has been wellbotanized in the last years, but a rare, inconspicuous plant like this requires a specifically designed search, and this has not been conducted. Additionally, there are yet extensive tracts of suitable habitat that may harbor populations of $M$. lyonnetii. In other probable but excluded cases a single record exists, supposedly collected in Mexico, of a taxon that is very likely not native to the country, and otherwise well-known from other geographic areas (e.g. Eulophia filicaulis Lindl. -previously known as E. ramifera Summerh.- from Africa, see Salazar and Cribb, in press; or Maxillaria aurantiaca A. Rich. \& Galeotti, a supposedly Mexican taxon based on a cultivated plant, referable to the Brazilian Bifrenaria aureofulva (Hook.) Lindl.).

\section{Results and discussion}

Besides the topics discussed in this work, the data base is a source of important information to planning the conservation of the Mexican orchids at risk. For example, it records the regional declining and extirpation of most orchid populations at risk in the densely populated areas of Veracruz and Puebla, and how the same taxa may have healthy populations in Oaxaca. The data base is also an important tool because it gives precise and specific guidelines for ex situ conservation programs. It indicates which species are already propagated, which need urgent actions, which present particular difficulties for propagation, which may be traded in the international and national market, among other issues.

Populations at Risk and NATURAL PROTECTED AREAS. Only 120 of the nearly 200 Mexican orchids at risk have populations located inside the System of Natural Protected Areas (SINANP; fig. 1). The sys- 


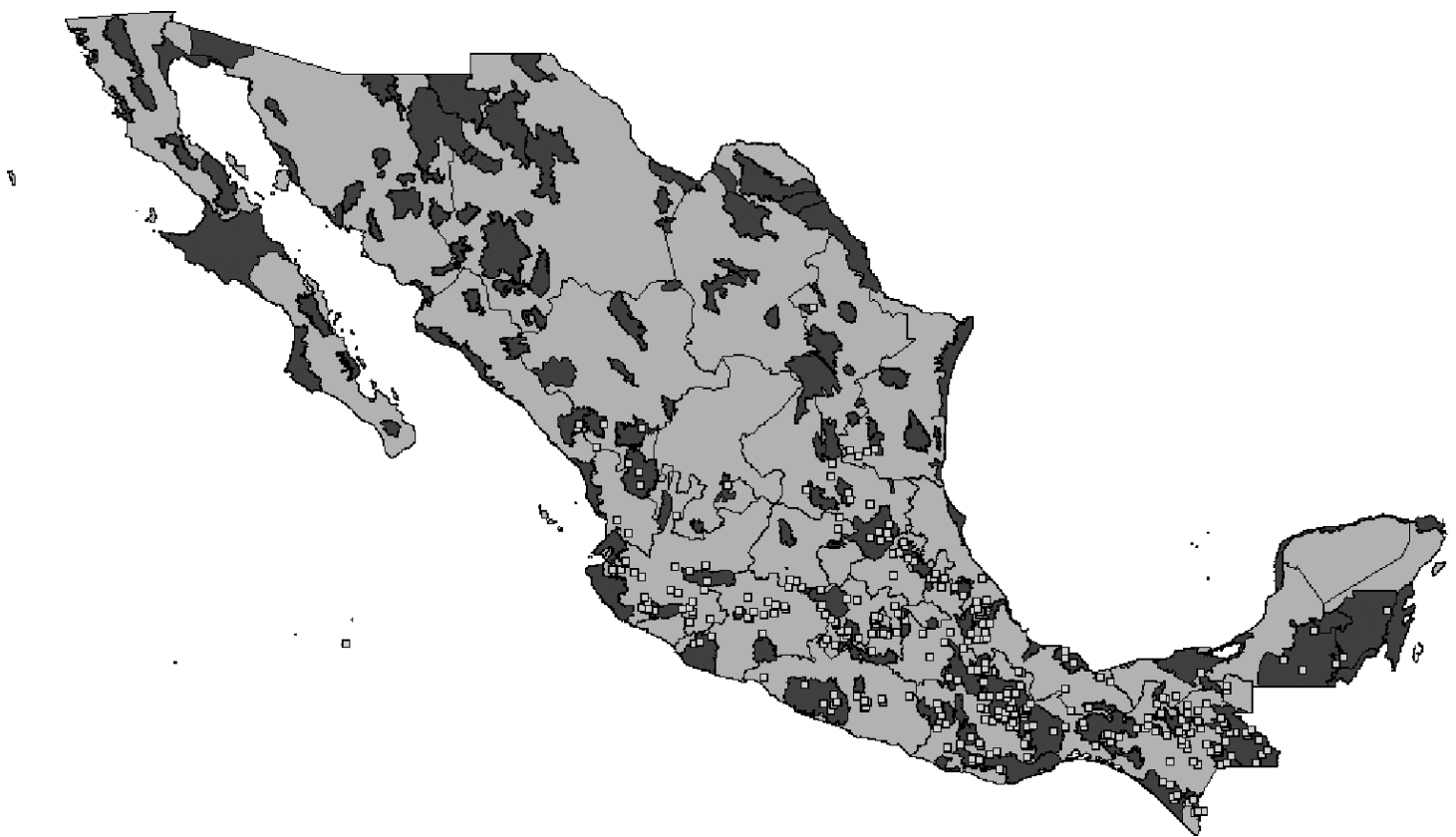

FIGURE 2. Localities of the Mexican orchids at risk (squares) and terrestrial prioritary regions for conservation (dark gray; Arriaga et al., 2000). There are 152 prioritary regions but only in 49 have populations of orchids at risk, most of them in the southern part of the country. Of the 183 species at risk included in the NOM-059-ECOL-2001, 171 have populations in the prioritary regions; which indicates that these regions were appropriately selected.

tem is insufficient to fulfill the strategy of conservation in situ. Mexican orchid alpha diversity (the diversity into the sites) is rather high in some areas, but at national scale beta diversity (the diversity between sites) is much more important. The biological diversity is widely distributed and it is being maintained by the high environmental heterogeneity, that is, well-defined endemism areas and high beta diversity, as recently stressed in an orchid diversity analysis of the State of Oaxaca (Soto Arenas \& Salazar 2004). This means that in order to maintain the biodiversity of the country, the System of Natural Protected Areas must encompass different habitats in different biotic provinces. It is evident that natural protected areas are absent, or almost, in cloud forested regions and in some biotic provinces, like the Sierra Madre del Sur, which has the higher proportion of endemics.

The idea that the present natural protected areas are not sufficient to maintain the biodiversity of the country is not new. In consequence, government agencies and conservationist groups recognized priority terres- trial regions, somewhat equivalent to "hotspots" (regions that harbor biodiversity of global significance, but which are highly threatened). The priority areas attempt to serve the SINANP as a framework when considering the incorporation of new areas, but little effort have been done to date to convert priority regions in protected areas. As 171 orchid species at risk (more than $90 \%$ of the whole) have populations inside the priority regions (fig. 2), it is evident that these areas were properly selected and it must be an important task to guarantee that they can maintain their biodiversity. Certainly, the maintenance of orchid species in protected areas is not secured with an official decree, and much work has to be done to provide natural protected areas with management plans and surveillance; however, their official decree is an important first step.

RISK FACTORS. We determined for each one of the 183 orchid species in the NOM-059-ECOL-2001 the two main risk factors (for three species no risk factors are known, for 11 species only a single risk factor is evident). This can be summarized as follow: In 111 
species the intrinsic biological factors make then very vulnerable (high habitat specificity, hyperdispersed populations, particular life history, etc.). In 108 species one of their two major risks is the habitat destruction due to agricultural activities, coffee culture being by far the most important. In 49 species the cattle ranching as one of their major risks, with only one case due to goats grazing. In 32 species their habitat have been lost due to forest fires linked to extreme climatic conditions thought to be result of the climatic change. The collection of specimens for the local market is a major risk for 28 species and 21 species have it or had in the past, the collection of specimens for the international horticultural market. Forestry is a threat for 17 species. Four species are at risk due to urban or touristic developments. In three taxa the habitat conversion is the result of the activities to produce charcoal. Two species are at risk due to the industrial, extractive activities and mining. Two species are at risk due to degradation of their habitat because it is located too close to cities with acid rain and urban warming. In two species the plants have suffered severe defoliation and tissue damage by unusual, extremely severe frosts thought to be a result of the climatic change. In one species the habitat has been transformed by the change in the local hydrology of the station.

It is evident that intrinsic factors that make orchid species potentially vulnerable interact with anthropogenic factors that combined put them at risk. The most important is agriculture, cattle raising, and surprisingly the forest fires thought to be result of climatic change, since fires in communities like the mountain rainforest were very unlikely under previous conditions. These threats are followed by the collection to supply the demand of orchids as adornment or for horticulture. Although international trade with wild specimens is probably insignificant nowadays, it was important in the past and was the major threat for taxa like Laelia anceps subsp. dawsonii (J.Anderson) Rolfe, Phragmipedium exstaminodium Castaño, Hágsater \& E.Aguirre, or Rossioglossum grande (Lindl.) Garay \& G.C.Kenn., and the cause of their present endangered status. Collection of wild orchids to be sold in the local Mexican markets has been stressed as a very important threat for species like $L$. speciosa (Kunth) Schltr., Barkeria scandens (La
TABLE 1. Orchids extinct in Mexico. The following list includes those orchid species whose all known wild populations have been extirpated and that extinction has been verified by field work. Those species marked with an asterisk* were found only in the elfin forest-mountain rainforest of the region of Montebello, Chiapas. The year on the column of the right is the last date in which a wild specimen was seen or alternatively, when the last patch of suitable habitat disappeared.

\begin{tabular}{|c|c|}
\hline $\begin{array}{l}\text { Anathallis oblanceolata (L.O.Williams) } \\
\text { Solano \& Soto Arenas }\end{array}$ & 1987 \\
\hline $\begin{array}{l}\text { *Cochleanthes flabelliformis (Sw.) } \\
\text { Schultes \& Garay }\end{array}$ & 1977 \\
\hline *Dracula pusilla (Rolfe) Luer & 1998 \\
\hline *Dichaea tuerckheimii Schltr. & 1998 \\
\hline *Epidendrum culmiforme Schltr. & 1998 \\
\hline *Epidendrum pansamalae Schltr. & 1981 \\
\hline *Epidendrum tziscaoense Hágsater & 1998 \\
\hline *Eriopsis wercklei Schltr. & 1975 \\
\hline $\begin{array}{l}\text { *Jacquiniella gigantea Dressler, Salazar } \\
\text { \& García Cruz }\end{array}$ & 1998 \\
\hline Laelia gouldiana Rchb.f. & before 1888 \\
\hline *Lepanthes guatemalensis Schltr. & 1998 \\
\hline *Lepanthes minima Salazar \& Soto Arenas & 1998 \\
\hline $\begin{array}{l}\text { Lepanthes nigriscapa } \text { R.E.Schult. \& } \\
\text { G.W. Dillon }\end{array}$ & 1936 \\
\hline *Lepanthes stenophylla Schltr. & 1998 \\
\hline *Lepanthes yunckeri Amex ex Yunck. & 1998 \\
\hline *Lycaste dowiana Endres \& Rchb.f. & 1998 \\
\hline *Lycaste lassioglossa Rchb.f. & 1985 \\
\hline *Platystele caudatisepala (C.Schweinf.) & 1998 \\
\hline $\begin{array}{l}\text { Rossioglossum williamsianum (Rchb.f.) } \\
\text { Garay \& G.C.Kennedy }\end{array}$ & 1998 \\
\hline *Sigmatostalix guatemalensis Schltr. & 1998 \\
\hline $\begin{array}{l}\text { *Specklinia samacensis (Ames) Pridgeon } \\
\quad \& \text { M.W.Chase }\end{array}$ & 1998 \\
\hline *Trichosalpinx trachystoma (Schltr.) Luer & 1973 \\
\hline
\end{tabular}

Llave \& Lex.) Dressler \& Halb., Oncidium tigrinum La Llave \& Lex., Prosthechea karwinskii (Mart.) Soto Arenas \& Salazar, P. vitellina (Lindl.) W.E.Higgins, and many others (Hágsater et al. 2005). Extinction. Table 1 enlist 22 orchid species (no infraspecific taxa were considered) which we can say with certainty that are extinct in the wild in the country. Three of them, Anathallis oblanceolata (L.O.Williams) Solano \& Soto Arenas, Laelia gouldiana Rchb.f., and Lepanthes nigriscapa R.E.Schult. \& G.W.Dillon are endemic to Mexico; therefore they 
TABLE 2. Orchid species that are probably extinct in Mexico. Those species marked with an asterisk* were found only in the elfin forest-mountain rainforest of the region of Montebello, Chiapas. The year on the column of the right is the last date in which a wild specimen was seen or alternatively, when the last patch of suitable habitat disappeared.

\begin{tabular}{l|l}
\hline Epidendrum incomptoides Ames & 1925 \\
\hline $\begin{array}{l}\text { Erycina pumilio (Rchb.f.) N.H.Williams } \\
\text { \& M.W.Chase }\end{array}$ & 1971 \\
\hline *Habenaria wercklei Schltr. & 1998 \\
\hline Hapalorchis lineatus (Lindl.) Schltr. & 1981 \\
\hline Houlletia tigrina Linden ex Lindl. \& Paxton & 1989 \\
\hline Lyroglossa pubicaulis (L.O.Williams) Garay & 1910 \\
\hline Maxillaria oestlundiana L.O.Williams & 1984 \\
\hline *Maxillaria praestans Rchb.f. & 2002 \\
\hline Mormodes porphyrophlebia Salazar & 1976 \\
\hline Oncidium exauriculatum(Hamer \& Garay) & 1989 \\
\hline R.Jiménez & 1969 \\
\hline Oncidium wentworthianum Bateman ex Lindl. & 1935 \\
\hline Plectrophora alata (Rolfe) Garay & \\
\hline
\end{tabular}

are extinct on a global scale. Table 2 enlist 12 additional orchid species which are probably extinct in the country, also three of them, Epidendrum incomptoides Ames, Maxillaria oestlundiana L.O.Williams, and Mormodes porphyrophlebia Salazar are endemic. The present extinction rate of Mexican orchids is $1.75 \%$ but rises up to $2.71 \%$ if the species considered as probably extinct are included. On a global scale Mexico may have contributed with three (or six) already extinct endemic orchid species. From a single species thought to be extinct in 1900 , the number increased to about eight species in 1970, and since then it has had an exponential rising, that accelerated in 1998, to reach the present estimate of 34 species.

Greuter (1995) estimated that the extinction rate in Mediterranean higher plants was of $0.15 \%$ at the species level, while a rate of $0.14 \%$ is derived from the 1997 IUCN Red List of Threatened Plants. While the extinction rates in Mexican orchids are difficult to compare with these global estimates because many species range beyond the Mexican boundaries, $0.24 \%-0.48 \%$ of the endemic Mexican orchids are extinct or probably extinct. Extinction rate in Mexican orchids seems to be comparatively high, especially if we consider that no orchid species are thought to be extinct in areas like the West Indies and
Guyanas, and only one is probably extinct in the Paleartic region. The present orchid extinction rate in Mexico is higher that those estimated a decade ago for Southern Africa (0.21\%) and Australia (0.625\%), although lower than the $3.6 \%$ calculated for the Indian subcontinent (data derived from the regional accounts, IUCN/SSC Orchid Specialist Group 1996).

The extinct species share some common traits, especially distributional and habitat preferences. Of the 34 (certainly and probably) extinct Mexican orchids, 28 are species restricted to the mountain rainforest of Chiapas, 22 of them previously found only in the region of Montebello. Four additional species were narrow endemics previously found in the lower mountain rainforest of little extent in the Pacific slope of Oaxaca and Guerrero (the Pluma Hidalgo area and the base of the Teotepec system). Only two taxa have unique distributional traits. Laelia gouldiana is a taxon whose specific status is questionable. It has never been found in the wild, its original range is unknown, and recent molecular data (Soto Arenas and Márquez, unpubl. data) suggest that it is a hybrid between L. autumnalis (La Llave \& Lex.) Lindl. and $L$. anceps Lindl., two taxa which are not sympatric at present. It is probable that Laelia gouldiana is the result of an ancient hybridization event. The other particular case is that of Lyroglossa pubicaulis (L.O.Williams) Garay, a terrestrial species known from a tropical area of quarzic, acidic sands in southern Veracruz. This habitat is uncommon in the country and it has been subject to severe human impact due to oil extraction, mining, and livestock raising.

The 32 (certainly and probably) extinct Mexican orchids whose habitat was the mountain rainforest share some things in common. They were strict in habitat preferences, for example found only in primary, particularly humid spots of the forest; all were epiphytes that usually had an extralimital distribution in Mexico, most with only one or two populations in the country which may be termed peripherical stations. However, there is a large variation in other traits, some were common plants, others with hyperdispersed populations, some are showy species subject to collection and trade, others are inconspicuous miniatures unknown in cultivation, etc. In most cases the habitat was also severely impacted by agricultural 
activities, coffee culture being the very important threat in each and every case. In the case of the 22 species restricted to the mountain rainforest of the Montebello region, their extirpation was due to forest fires that completely destroyed the habitat. Crown forest fires were previously unknown in such a wet habitat and they were conditioned by the vegetation damage during the severe frosts of the winter of 1997-1998, the extreme drought in the spring of 1998, and the use of fire in the management of agricultural and cattle grazing areas. The extreme climatic conditions dried the epiphytic loads to convert them in a suitable fuel for the crown fires.

Extinction was therefore a gregarious event important in marginal (or of little extension), diverse habitats which were sensitive to the effects of the climatic change, and where bad management practices prevailed. It is therefore prioritary to recognize which habitats are the most vulnerable in order to foresee these gregarious losses. For example, the patches of moist coniferous forest in Coahuila and Nuevo León, surrounded by arid regions could be very sensitive to extreme climatic conditions (wildfires already destroyed large tracts in 1975, near San Antonio de las Alazanas, Coahuila). The relictual lower mountain rainforests of southern Oaxaca and Guerrero have been already listed as very threatened habitats (Soto Arenas 1996). The ravines with evergreen tropical forest near El Tuito, Jalisco, which harbor the only populations of rainforest plants in western Mexico, could be also very vulnerable.

Habitat condition is intuitively less adequate in peripherical populations than in the middle of the species' distribution (Olson et al. 2005). Climatic change should cause dramatic reduction in the ranges of many species by eliminating the peripherical, outlying populations. Extinction of the orchids of the mountain rainforest of Chiapas means clearly a contraction of the species' ranges. Although researches have stressed that animal species' responses to climate change are individualistic (Team species 2003), plant communities are assemblages in which some components share a high fidelity to the habitat, and therefore plant species' responses may be similar.

In this work we show data, if circumstantial, that climate change is an orchid threat, perhaps much more dangerous and imminent that previously real- ized. The social and economic problems that provoke a bad management of the environment combine in a bad way with climatic change to be together, by far, the most important extinction threats in Mexico. Collecting evidence on this combined threats and quantifying its effects are a prioritary task for orchid conservation.

ACKNOWLEDGEMENTS. We thank CONABIO the financial support through the Projects R225 (Diversidad de Orquídeas en la Región El Momón-Las MargaritasMontebello, Chiapas, México) and W029 (Información actualizada sobre las especies de orquídeas en el ProyNOM-059-ECOL-2000). We thank Elleli Huerta Ocampo, SEMARNAT, for comments to a previous draft.

\section{LiTERATURE CITED}

Arriaga, L., J. M. Espinoza, C. Aguilar, E. Martínez, L. Gómez \& E. Loa (coordinators). 2000. Regiones terrestres prioritarias de México. Comisión Nacional para el Conocimiento y Uso de la Biodiversidad. México.

CONANP. 2006. Areas naturales protegidas federales de México. Comisión Nacional de Areas Naturales Protegidas. Morelia, México.

González Tamayo, R. 2002. Malaxis (Orchidaceae), breve discusion de los rasgos específicos y dos taxones nuevos mexicanos. Ibugana 10(1-2): 67-75.

Greuter, W. 1995. Extinctions in Mediterranean areas. In: J. Lawton \& R. May (eds.). Extinction rate. Oxford University Press.

Hágsater, E. \& M.A. Soto Arenas. 1998. Orchid conservation in Mexico. Selbyana 19(1): 15-19.

Hágsater, E., M.A. Soto Arenas, G.A. Salazar Chávez, R. Jiménez Machorro, M.A. López Rosas \& R.L. Dressler. 2005. Las orquídeas de México. Instituto Chinoín, México, $304 \mathrm{pp}$.

IUCN/SSC Orchid Specialist Group, 1996. Orchids Status survey and conservation action plan. IUCN, Gland, Switzerland and Cambridge, UK.

Olson, M.E., J.A. Lomelí \& N.I. Cacho. 2005. Extinction threat in the Pedilanthus clade (Euphorbia, Euphorbiaceae), with special reference to the recently rediscovered E. conzattii (P. pulchellus). Am. J. Bot. 92(4): 634-641.

Rawinowitz, D., S. Cairns \& T. Dillon. 1986. Seven forms of rarity and their frequency in the flora of the British Isles. Pp. 182-204 in: M.E. Soulé (ed.) Conservation biology, the science of scarcity and diversity. Sinauer, Sunderland, Mass.

Salazar Chávez, G.A. 1997. A new species of Malaxis 
(Orchidaceae) from Morelos, Mexico. Brittonia 49: 449-451.

Salazar Chávez, G.A. \& P.J. Cribb (in press). On the identity of Eulophia filicaulis Lindl. (Orchidaceae). Kew Bull.

Soto Arenas, M.A. 1994. Population studies in Mexican orchids. Pp. 153-160 in: A. Pridgeon (ed.). Proceedings of the $14^{\text {th }}$ World orchid conference. HMSO, Edimburgh.

Soto Arenas, M. 1996. Regional Accounts: Mexico. Pp. 53-58 in IUCN/SSC Orchid Specialist Group. Orchids Status survey and conservation action plan. IUCN, Gland Switzerland and Cambridge, UK.

Soto Arenas, M.A. \& E. Hágsater. 1990. Algunas ideas acerca de la conservación de las orquídeas mexicanas y un listado preliminar de los taxa amenazados. Pp. 155172 in: J.L. Camarillo \& F. Rivera (eds.). Áreas naturales protegidas y especies en extinción. Universidad Nacional Autónoma de México, Mexico City.
Soto Arenas, M.A., E. Hágsater, R. Jiménez Machorro, G. Salazar Chávez, R. Solano Gómez \& R. Flores. 2007. Las orquídeas de México. catálogo digital. Instituto Chinoín, A.C., Mexico City. DVD.

Soto Arenas, M.A \& G.A. Salazar Chávez. 2004. Orquídeas. Pp. 271-295 in: A.J. García-Mendoza, M.J. Ordoñez \& M. Briones-Salas (eds.). Biodiversidad de Oaxaca. Instituto de Biología, UNAM-Fondo Oaxaqueño para la Conservación de la NaturalezaWorld Wildlife Fund, México City.

SEMARNAT. 2002. Norma Oficial Mexicana NOM-059ECOL-2001, Protección ambiental-Especies de flora y fauna silvestres de México-Categorías de riesgo y especificaciones para su inclusión, exclusión o exclusión-Lista de especies en riesgo. Diario Oficial de la Federación, 6 de marzo de 2002. México.

Team species. 2003. Climate changes species survival. Species 39: 8 .

Miguel Ángel Soto Arenas is a research associate with the Herbario AMO, Mexico City, since 1984; he has been executive editor of the journal Orquidea (Mexico City) and editor of the last fascicles of "Orchids of Mexico". He is particularly interested in the systematics of Vanilla, Epidendrum, and the floristics, origin, and conservation of the Mexican orchid flora.

Rodolfo Solano Gómez is a professor at the Instituto Politécnico Nacional in Oaxaca, Mexico. He received his doctorate at the Universidad Nacional Autónoma de México. His interests in orchids are focused in the systematics of the subtribe Pleurothallidinae and during the last decade he has been contributing with taxonomic treatments of this group. At present he is working with the orchids of Oaxaca and maintains collaboration with the Herbario AMO.

Eric Hágsater has been Director of the Herbario AMO since 1976; he is a recognized specialist in the genus Epidendrum, with more than 130 publications on the topic, as well as on the taxonomy and conservation of Neotropical orchids. He has been editor of Orquídea (Mexico City) and Icones Orchidacearum, and Chair, IUCN/SSC Orchid Specialist Group, from 1984 to 1997. Since 1994 he is member of the technical committee of Remib (Biodiversity Information World Net), an interinstitutional network formed by the research centers which host scientific collections. 